\title{
Teacher Character Strengths and Talent Development
}

\author{
Rosadah Abd Majid ${ }^{1}$, Manisah Mohd Ali $^{1} \&$ Aliza Alias $^{1}$ \\ ${ }^{1}$ Faculty of Education, Universiti Kebangsaan Malaysia, Malaysia \\ Correspondence: Rosadah Abd Majid, Faculty of Education, Universiti Kebangsaan Malaysia, 43600 UKM \\ Bangi, Selangor, Malaysia. Tel: 603-8921-6463. E-mail: rosadah@ukm.edu.my
}

Received: July 22, 2014 Accepted: November 5, 2014 Online Published: December 21, 2014

doi:10.5539/ies.v7n13p175

URL: http://dx.doi.org/10.5539/ies.v7n13p175

\begin{abstract}
Students are the nation's asset or natural resources who need to be educated to achieve their optimal level of development. They need to be properly nurtured to allow holistic development in all domains namely; physical, mental, social, emotional, and spiritual. This is crucial for the building of a strong and respectful nation and its civilization. Teachers are entrusted to educate students. Educating is more than just mere teaching. It is necessary for teachers to possess good characters to be supportive and accommodative of their students' learning needs, and to nurture students' intra and interpersonal skills the crucial elements in developing gifts into talent as proposed by the Differentiated Model of Talent Development (DMGT). This paper discusses teachers' characteristics and the underlying character strengths. Character strengths are positive psychological ingredients, which influence thinking, feeling, and behaving. A qualitative survey was carried out via face book social network, to capture respondents' reflections on their teachers' characters that have affected them positively. The respondents were university students and graduates from many different fields of studies. They were from prestigious schools where only academically talented students were selected to enroll. They were invited to response to this posting; 'Dear friends, please feed me with some data from your own reflection. What teachers' characters have affected you positively? Thank you for sharing". Thirty one people had responded to the posting. Their responses were analyzed to identify themes that described their teachers' characters, which had affected them positively. Three most frequent character strengths identified by the respondents were; wisdom and knowledge, humanity, and transcendence.
\end{abstract}

Keywords: teacher character, talent development, wisdom

\section{Introduction}

Educating students is not just teachers' responsibilities. More than that, teachers are accountable for the students' developmental process. Accountability takes a person higher than carrying responsibility because one will be answerable to the stakeholders regarding his/her responsibilities and its' outcome. Educators and teachers need to stop and ask ourselves, are we doing enough to fulfill this demand of accountability, and have we played our roles significantly in developing wise and well-mannered academically talented students. Educators are facing very demanding tasks indeed, which require them to be ahead in enhancing themselves with distinctive qualities necessary in educating their students. Teachers will need to win their students' hearts before being able to mould the students' character. Good character is referring to stable and distinctive qualities of a person, significant of his/her underlying complex mental and ethical traits, marking the person's wisdom in doing the right things.

Teacher character is referring to the teacher's personal distinctive qualities, which are significant of his/her, complex mental and ethical traits. This is referring to the teachers' behaviors and how those behaviors are affected by the values that the teachers are adhering to. Peterson and Seligman (2004) listed six dimensions of character strengths (Figure 1). Character strengths influence thinking, feeling, and behaving. They are positive psychological ingredients for a flourishing life. The six character strengths are; wisdom and knowledge, courage, humanity, justice, temperance, and transcendence. The strength of wisdom and knowledge is referring to; creativity, curiosity, opens mindedness, love of learning, and wise perspectives. Courageous persons are brave, persistence, demonstrate integrity and vitality. Humanity character is referring to love, and kindness, which include generosity, nurturance, care, compassion, altruistic love, and "niceness". Humanity also includes social intelligence, which encompasses emotional intelligence, and personal intelligence. The sense of justice, which is the fourth character strength, encompasses leadership, fairness, and citizenship, which include social responsibility, loyalty, and teamwork. The fifth character strength, the temperance encompasses forgiveness and 
mercy, humility and modesty, prudence, and self-regulation or self-control. Transcendence is the sixth character strength, and it encompasses appreciation of beauty and excellence, gratitude, humor, spirituality and hope, which include optimism, future mindedness, and future orientation.

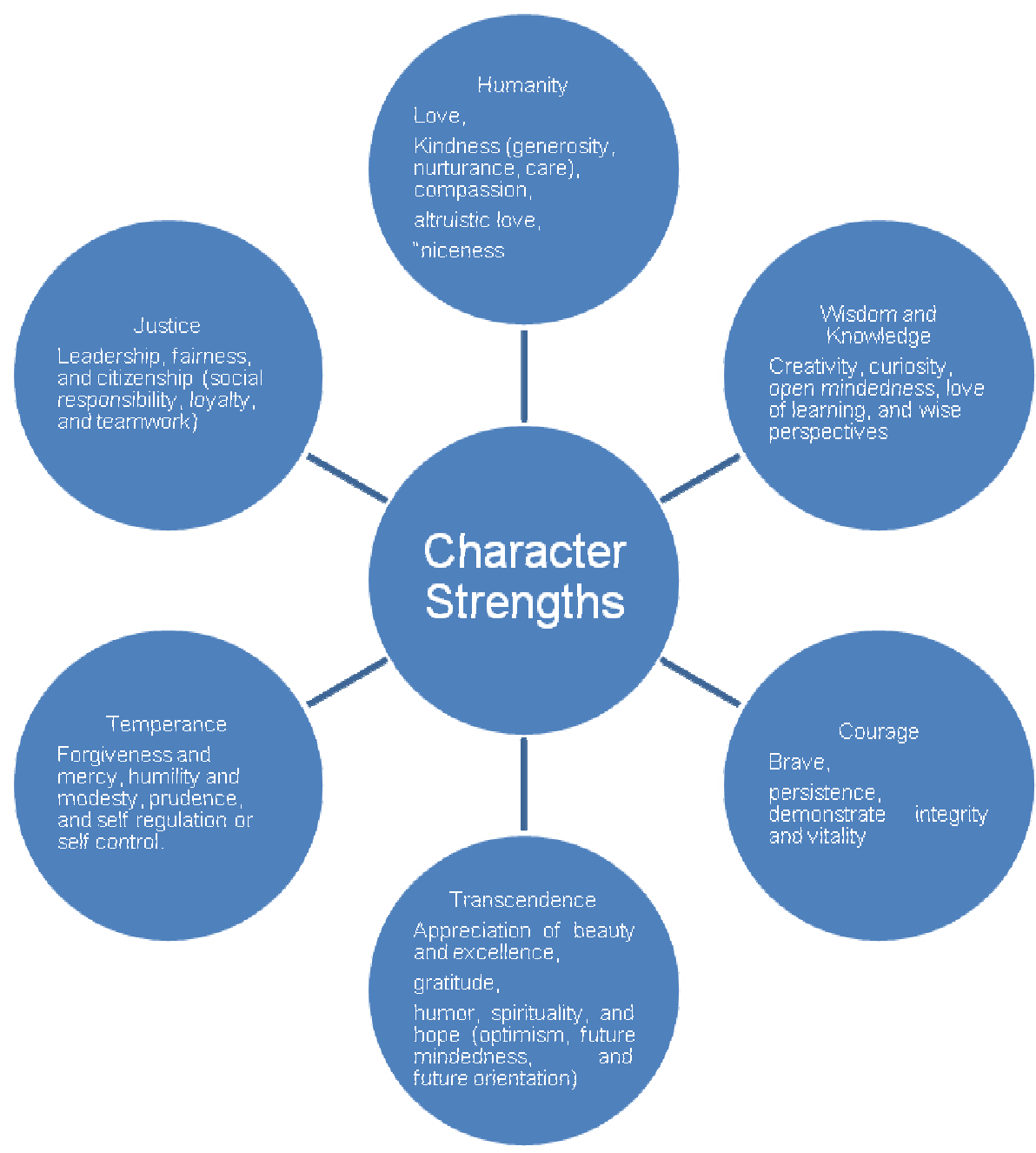

Figure1. Six dimensions of character strengths adapted from Peterson and Seligman (2004)

How people live their life is determined by their character. People with the character quality of tolerance will be more accepting of others, and they are less prejudiced. A person who is forgiving would not be affected by words of sarcasm that are targeted towards him/her. The list can go on to include all the good character qualities and how those character influence one's attitude and behavior. This will convince us that inculcating good character in today's education system is important and necessary. Opuni, Washington, and Giddings (2012) referred to high incidence of fights, bullying, suspensions, youth gangs, generalized display of respect, and low achievement level, as symptoms of character degeneration. This again emphasizes the importance and the need for teaching and coaching good characters to students, because it will mould their attitudes. Teachers play significant role in carrying out this responsibility, and their own characters matter as well. Orlando (2013) mentioned that teachers' attitudes towards their students, the subject taught, and their work is very important in their effort of providing challenging and nurturing learning environment. Orlando (2013) listed nine characteristics of a great teacher:

a. A great teacher respects students. In a great teacher's classroom, each person's ideas and opinions are valued. Students feel safe to express their feelings and learn to respect and listen to others. This teacher creates a welcoming learning environment for all students.

b. A great teacher creates a sense of community and belonging in the classroom. The mutual respect in this 
teacher's classroom provides a supportive, collaborative environment. In this small community, there are rules to follow and jobs to be done and each student is aware that he or she is an important, integral part of the group. A great teacher lets students know that they can depend not only on her, but also on the entire class.

c. A great teacher is warm, accessible, enthusiastic and caring. This person is approachable, not only to students, but to everyone at school or on campus. This is the teacher to whom students know they can go with any problems or concerns or even to share a funny story. Great teachers possess good listening skills and take time out of their way-too-busy schedules for anyone who needs them. If this teacher is having a bad day, no one ever knows - the teacher leaves personal baggage outside the school doors.

d. A great teacher sets high expectations for all students. This teacher realizes that the expectations she has for her students greatly affect their achievement; she knows that students generally give to teachers as much or as little as is expected of them.

e. A great teacher has his own love of learning and inspires students with his passion for education and for the course material. He constantly renews himself as a professional on his quest to provide students with the highest quality of education possible. This teacher has no fear of learning new teaching strategies or incorporating new technologies into lessons, and always seems to be the one who is willing to share what he has learned with colleagues.

f. A great teacher is a skilled leader. Different from administrative leaders, effective teachers focus on shared decision-making and teamwork, as well as on community building. This great teacher conveys this sense of leadership to students by providing opportunities for each of them to assume leadership roles.

g. A great teacher can "shift-gears" and is flexible when a lesson is not working. This teacher assesses his teaching throughout the lessons and finds new ways to present material to make sure that every student understands the key concepts.

h. A great teacher collaborates with colleagues on an ongoing basis. Rather than thinking of herself as weak because she asks for suggestions or help, this teacher views collaboration as a way to learn from a fellow professional. A great teacher uses constructive criticism and advice as an opportunity to grow as an educator.

i. A great teacher maintains professionalism in all areas - from personal appearance to organizational skills and preparedness for each day. Her communication skills are exemplary, whether she is speaking with an administrator, one of her students or a colleague. The respect that the great teacher receives because of her professional manner is obvious to those around her.

Loreman (2011) proposed love as the basis for pedagogy. The emphasis is on kindness, empathy, bonding, sacrifice, and forgiveness. Love was explained and discussed from three different perspectives; psychological, religious, and philosophical. Where the three overlaps marks the basis for loving one's professions, students, and the intangible rewards. Love can inspire people to learn (Cho, 2005).

\subsection{Giftedness and Talent Development}

Gifted education is a field of study which looks into the science of educating our most able students in schools. Despite facing issues of elitism and equity in education, this field of study has grown, and has managed to gauge the focus of education in many countries (Colangelo \& Davis, 2003). Giftedness is referring to natural abilities among mankind, or outstanding aptitudes in at least one of the domains of giftedness, that places the person within $10 \%$ of his/her age peers (Gagne, 2008). Talent is referring to outstanding mastery of systematically developed abilities or competencies in at least one field of human activity, which put the talented person to be among the top $10 \%$ of his/her age peers. The path of talent development from aptitudes or giftedness was explained via Gagne (2008) Differentiated Model of Talent Development (DMGT) in Figure 2. Teachers play critical roles in enhancing the environmental milieu, and in enhancing the students' personal traits to reach to their optimum level of talent development from the potentials of giftedness. These teachers' factors include the importance teachers' characters that are capable of enhancing and nurturing good attitudes among gifted students. This fits in the Gagne's model as catalyst for talent development.

Some gifted students experience difficulties relating and socializing with people around them (Piirto, 1999; Van Tassel-Baska, 1998). This could be due to their uneven or asynchronous development. They may experience advancement in cognitive development, but lags in emotional domains (Piirto, 1999). Teachers of the gifted need to pay considerable attention to develop their students holistically. Aristotle argued that "educating the mind without educating the heart is no education at all." This is referring to the importance of paying attention to the affective domain of teaching and learning activities. Affective means what is thought is connected with emotions, which in consequence affect the attitudes. The socio-affective characteristics were triggered by deep emotions, 
feelings, attitudes, and perceptions one has towards certain remarks made by other people in his/her surrounding, whom he/she interacts socially. It could also be due to the social phenomenon or social issues around the students. Behavioral characteristics observed during social interactions usually were emotionally driven. It is also true when referring to one's behaviour or reactions in relation to his understanding brought about by his social interactions. When gifted students are capable to comprehend the issues they will feel so deeply about it. Mix with the characteristics of over excitabilities or sensitivity to others or to certain issues, they could be critical to their own self and to others (Schuler, 2001).

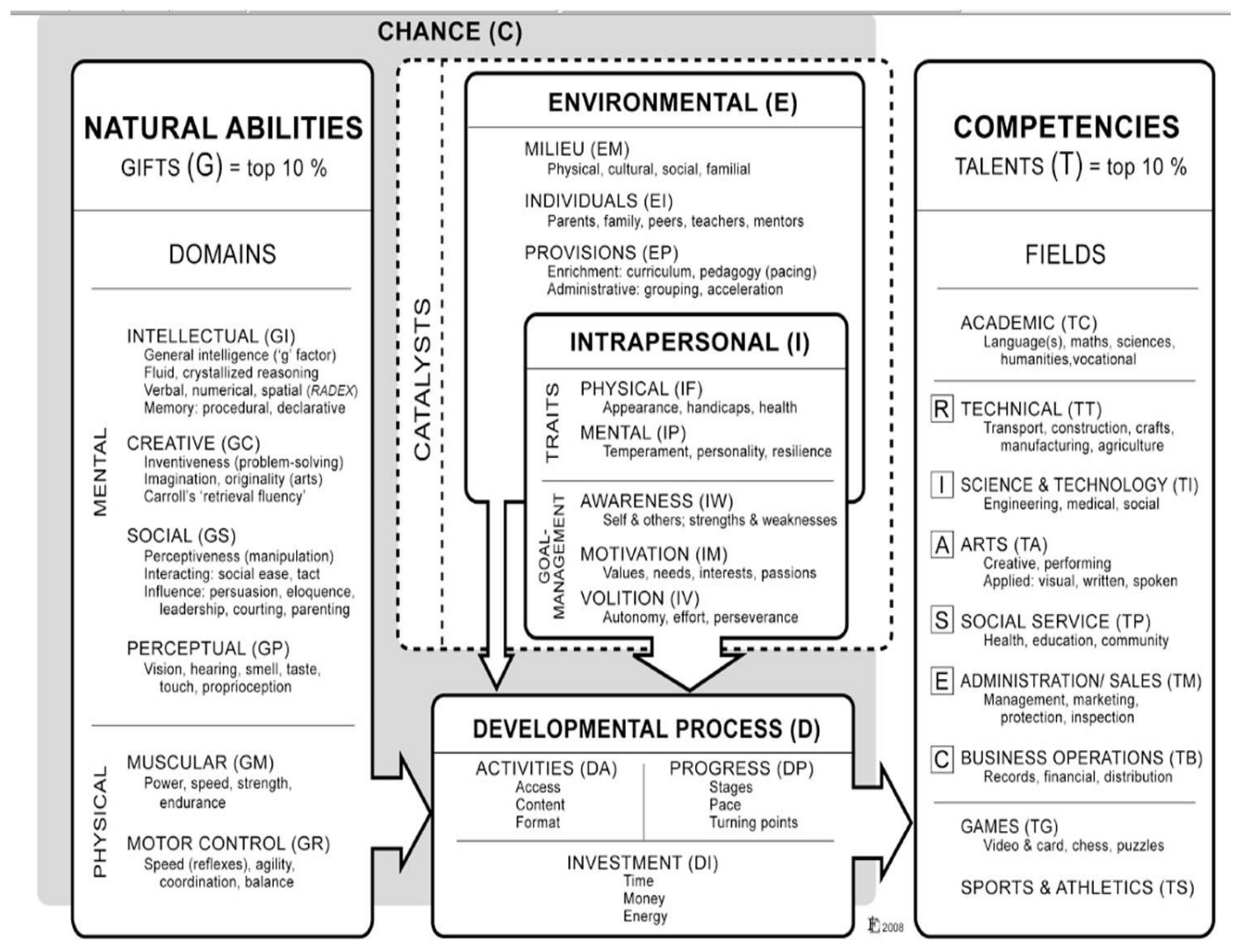

Figure 2. Gagne (2008) Differentiated Model of Talent Development (DMGT)

The emotions of a gifted student affect his own behaviour and of others around him. The emotions and reactions of other people around the gifted students also affect the gifted students' emotions and reactions. Gifted students often experience emotional intensity and exhibit the following observable affective characteristics at a certain degree; a sense of justice, altruism and idealism, high levels of energy, strong attachments and commitments, aesthetic sensitivity, sense of humor, emotional intensity, early concern about death, and perfectionism (Van Tassel-Baska, 1998). Teachers of the gifted need to understand those special characteristics and the learning needs of the students. They will have to be accommodative of the students' thoughts and feelings, and to facilitate the students to interpret and reinterpret experiences and life events. This calls for wisdom in teaching and in dealing with the gifted students.

Feldhusen (1997) explored the kinds of teachers preferred by gifted students. The teachers need to be enthusiastic, energetic, patient, sensitive, respectful, emphatic, honest, and objective. This list continues to include other characteristics and approaches to teaching employed by exemplary teachers as quoted by gifted students (Table1). Having teachers with those characteristics fulfill the element of catalyst in Gagne DMGT Model. Teachers of the gifted motivate their students, help the students to understand themselves and others, and guide the students to be autonomous and persevere. In addition, teachers with these qualities play their roles to enhance the developmental process (D) of gifted students when facilitating appropriate learning processes and activities (DA), and monitoring the students' progress and stages of learning (DP). 
Table 1. Exemplary teacher of the gifted: characteristics

Exemplary teacher of the gifted:

Are highly intelligent.

Are enthusiastic about giftedness, talent, and learning.

Are aware of gifted students' needs.

Are energetic, ready to do extra work, and ready to experiment.

Are patient, sensitive, respectful, and emphatic: they understand and see matters from students' point of view.

Recognize individual differences, including personal self-images and personal integrity.

Accept responsibility for individual children.

Create a vibrant, safe, warm, and democratic learning environment.

Are less judgmental and critical; have confidence in gifted students.

Are imaginative, innovative, flexible, and open to change.

Have cultural and intellectual interests and broad general knowledge.

Are honest, fair, and objective.

Are mature, experience, and self-confident.

Are willing to learn with and from students; are perennial students themselves.

Seek new solutions through continued learning.

Have control over their personal lives.

Can work closely with other members of gifted staff, students, parents, and other professionals.

Can communicate the needs of gifted children and muster support for the gifted program.

Have knowledge of the nature and needs of the gifted.

Guide and facilitate learning but do not coerce.

Can work with culturally different gifted students.

Help develop students' self-concept.

Motivate students to strive for high achievement, successful accomplishments, and general excellence.

Adapted from Feldhusen (1997).

\section{Survey on Teacher Character}

A qualitative survey research was conducted to study students' perspectives on teachers' character. Jansen (2010) mentioned that qualitative survey focuses on the diversity of the responses or data from a population. Unlike quantitative survey, which counts the number of people with the same characteristics, qualitative survey establishes meaningful variations within population (Jansen, 2010) A qualitative survey was carried out via face book social network, to capture respondents' reflections on their teachers' characters that have affected them positively. Respondents were university students and graduates from many different fields of studies. They were from prestigious schools where only academically talented students were selected to enroll. Some were from a discussion group on education, and a few were from an alumni group from a university abroad. They were invited to response to this posting; "Dear friends, please feed me with some data from your own reflection. What teachers' characters have affected you positively? Thank you for sharing".

Thirty one people had responded to the posting. Their responses were reflectively analyzed (Mason, 2002) to identify themes that described their teachers' characters which had affected them positively. The data then were deductively categorized into five different types of teachers' characteristics.

\section{Findings}

Five important themes had evolved from the data to confirm the earlier findings on exemplary teachers' characteristics (Feldhusen, 1997), and in line with nine characteristics of a great teacher Orlando (2013). The responses described how teachers had meaningfully affected students' lives. The teachers' characteristics identified were; good at enhancing students' motivation, have futuristic outlook, appreciative of their students, 
passionate about the subjects they taught, and actively shaping students' good attitude. These characteristics fall into three dominant characters strengths; wisdom and knowledge, humanity, and transcendence (Peterson \& Seligman, 2004). The most frequent character strength among the teachers that had affected their students positively is humanity. Humanity character strength is based on love, compassion, and above all on altruistic love that led a person to forgo his/her own interest in replace of others. This character strength transmits kindness, which includes generosity, nurturance and care. The themes for teachers' characteristics were identified from the respondents' statements as captured below.

\subsection{A Teacher Who Motivates}

A third year law student had expressed her gratitude to a teacher who would start her class with motivational and inspirational talk before she began her lesson. Sharing good values with students, genuinely concern for their well-being, will allow the students to see and evaluate how far the teachers regard them as important. Thus, students need and welcome continuous reminders to motivate them.

“...she takes 10 minutes before her class to share with us moral values and she tells us about life and things we should do and shouldn't, and things she reads from motivational books, we were all 19 years old but trust me it's all in my brain till now and it did help me make many important life decisions...!".

(A third year law student)

"I am attracted to teachers who frequently motivate students with motivations that really suit the students, when she talked for sure it would touch your heart..."

(A special education teacher)

Teachers who inspire and motivate their students have the character strength of humanity. They take the responsibility of nurturing their students and will be regarded as "nice teachers" by the students.

\subsection{A Teacher Who Has Futuristic Outlook}

An acquaintance who is a teacher himself mentioned the importance of having a teacher who is versatile and sensitive to futuristic outlook.

"I really enjoy my teachers who could jump out off the textbooks, talking about the future trends and challenges. Teachers who do not replay stereotyped experiences but who could enlighten students about things not yet in the market...

(A senior teacher)

This characteristic describes a teacher with transcendence character strength. A person who show gratitude, appreciate beauty and excellence, optimistic, future mindedness with future orientation.

\subsection{A Teacher Who Makes Their Students Feel Important}

A few responses to the posting confirm that students feel appreciated if teachers took the trouble to pay attention to their thoughts. This makes students feel important and convey to them that their teachers notice them. Those acts are categorized as "niceness" which allows a teacher to show their compassions and care. This is also rooted in humanity character strength.

"It is how much a teacher cares by remembering little details about you, it excites us as students when teachers do remember, but I know a teacher is only human and not everyone can juggle home and school in their mind but when they do, it means so very much!"

(Ex-student from a prestigious school)

"I had one BM teacher. She always listens to what we have to say. She will laugh at the right place! She really made an impression...luv her"

(A special education teacher)

"My English teacher. I remember his uniqueness, the way he emphasizes on words...small sense of pride when you were sincerely complimented on your reading..."

(Ex-student from a prestigious school)

"The teacher that I remember the most are those that treated me like I matter, my thoughts matter."

(Ex-student from a prestigious school) 


\subsection{A Teacher Who Is Passionate About His/Her Subject}

Students observed that teachers who loved the subjects they taught, and care for their students' learning would be willing to give time and effort to do their best in their teaching. This leaves a positive impression on their students, which is lasting and a precious one. Teachers who exhibits open mindedness and love of learning do so because they possess wisdom and knowledge as their character strength.

"Passion and love. A teacher asked us to request to the Head master to exchange the American Peace Corp with him when he realized that we were not able to understand what the American was teaching. So he offered himself hoping that we will understand what add math is all about...”

(Alumni group from a university abroad)

“...I remember the Geography teacher. She was so well versed in her subject matter, is always well prepared and teaches from her head i.e. not reading from the book. She draws maps freehand on the board and feeds us with the facts so well organized and everything is so well articulated that you remember those facts so well that that you need not revise too much but the details stick in your head. By the way needless to say I have an A in Geography."

(Ex-student from a prestigious school)

\subsection{A Teacher Who Has Agenda to Shape the Students' Attitudes}

Teachers' believe and their words could mould their students' thoughts. What was conveyed to the students would have a great impact on the students' attitudes. Teachers have such a big influence on the development of students' self concept. These teachers who believe in nurturing possess humanity character strength.

"In college, there was this lecturer who day in day out reminded us, never to judge. She said, whatever you become; a teacher, a lawyer, a doctor, a nurse, a stewardess, a business person, you will have to deal with people and to optimize your skill(s) remember what I taught you about not judging. It sounded rather simple or even cliché as a young adult at the time. However, looking at things and my life now, I might admit that the experiences I've had dealing with people whether professionally or socially have helped me ease through it all from not judging at the first meeting."

(A graduate from a university abroad)

"Once upon a time when I was in form four, my maths teacher said; approach a complex maths problem by breaking it down into easy logical steps. That is also how you should manage your daily chores"

(Alumni group from a university abroad)

\subsection{Teacher Character as Catalyst in DMGT}

Both the qualitative survey and the literature review that were carried out had confirmed that teachers played significant role in the development of their students. Teachers' factor is very important in the developmental process, transforming from the state of natural abilities or giftedness to achieve the standard of competencies and become talented. Among the teachers' factor is the teacher character. Teacher character could be regarded as a mediating catalyst for talent development, along with other environmental catalyst in DMGT (Figure 3). Although this model is for talent development, it is also suitable to explain human development in general. In this context, a catalyst helps to facilitate the process of development. Teachers with humanity character strengths have 'love' as the basis in their interaction with the students. This is in line with Loreman (2011) suggestion who proposed love as the basis for pedagogy. Three from five teachers' characteristics most remembered by the students fall into humanity character strength which subscribe to love as it's basis of action. The three teachers' characteristics are; teachers who motivate students, teachers who make their students feel important, and teachers who have agenda to shape their students' attitude. These teachers had indirectly assisted students in developing or enhancing their inter and intrapersonal skills. These skills are regarded as catalyst for talent development (Gagne, 2008). 


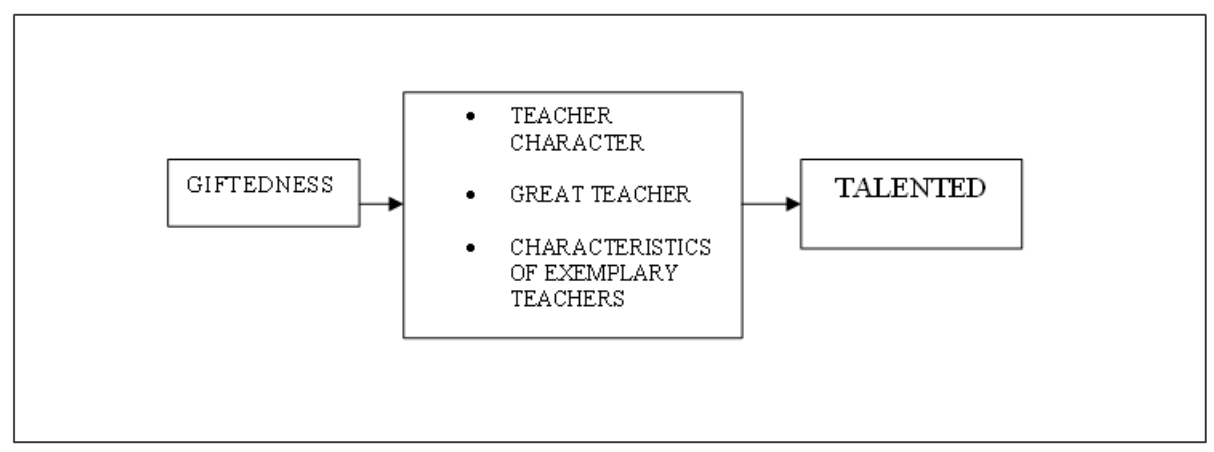

Figure 3. Teacher Character as Environmental catalyst in DMGT

Students' developmental process will have to subscribe to the importance of teachers' factor specifically the teacher character. This underlines the importance of efforts to enhance teacher character. In most cases, character strengths are learnt indirectly via observing others of exemplary qualities while internalizing their good values. People with exemplary qualities become the role models. Teachers are among the first role models that students encounter in the formal learning environment. Character strengths could also be taught directly by training people to acquire the desired character. It begins with understand of self and followed by willingness to improve one's self. It is about wisdom, love, humbleness and integrity.

\section{Conclusion}

The discussions in this paper focus on the need to emphasize on teacher character. A teacher need to teach their students holistically, and paying considerable attention to all the domains of teaching and learning namely; cognitive, affective and psychomotor. Teachers shall not only feed the students' mind with information and assisting them to understand the subjects taught, but teachers shall do the necessary to make their lessons meaningful to students. Students will grow to appreciate what was learnt, and to enjoy and appreciate the learning process itself. It is also necessary for educators to work on nurturing students' virtuous quality.

In this fast moving world where innovation is necessary to sustain life and to advance civilization, we need to educated and nurture our most able citizen to develop their true potential. If they fail to do so, when they achieve below their true potential we consider them as underachieving and it could be regarded as a tragedy to the family, to the nation, and to mankind in general. Educators for the gifted need to work diligently and be virtuous in their effort of educating the students. They do not only teach, but they need to coach, guide, support, mentor the students, and be role models for students. All these need virtue and wisdom among teachers in realizing students' true potentials. Gifted students need to learn to be diligent and wise citizens for their country and for the world.

\section{References}

Cho, D. (2005). Lessons of love: Psychoanalysis and teacher-student love. Educational Theory, 55(1), 79-96. http://dx.doi.org/10.1111/j.1741-5446.2005.0006a.x

Colangelo, N., \& Davis, G. A. (2003). Introduction and overview. In N. Colangelo, \& G. A. Davis (Eds.), Handbook of gifted education (2nd ed., pp. 189-197). Boston: Allyn \& Bacon.

Feldhusen, J. F. (1997). Secondary services, opportunities, and activities for talented youth. In N. Colangelo, \& G. A. Davis (Eds.), Handbook of gifted education (2nd ed., pp. 189-197). Boston: Allyn \& Bacon.

Gagne, F. (2008). Building gifts into talents: Overview of the DMGT. Retrieved from http://www.templetonfellows.org/program/FrancoysGagne.pdf

Jansen, H. (2010). The logic of qualitative survey research and its position in the field of social research methods. Forum: Qualitative Social Research,11(2).

Loreman, T. (2011). Love as pedagogy. Rotterdam: Sense Publishers. http://dx.doi.org/10.1007/978-94-6091-484-3

Mason, J. (2002). Qualitative researching (2nd ed.). London: Sage Publications.

Opuni, K. A., Washington, K. E., \& Giddings, J. M. (2012). Impact of caring teachers and character values instructions on student achievement in inner-city middle schools. Journal of Modern Education Review, 2(1), 1-8. 
Orlando, M. (2013). Nine characteristics of a great teacher. Teaching strategies for the college classrooms: A collection of faculty articles. Retrieved from http:/www.facultyfocus.com

Peterson, C., \& Seligman, M. E. P. (2004). Character strengths and virtues: A handbook and classification. New York: Oxford University Press.

Piirto, J. (1999). Talented children and adults: Their development and education. New Jersey: Merrill Prentice Hall.

Schuler, P. A. (2001). Perfectionism and the gifted adolescent. Journal of Secondary Education, 11, 183-196.

Van Tassel-Baska, J. (1998). Characteristics and needs of talented learners. In J. Van Tassel-Baska (Eds.), Excellence in Educating Gifted and Talented Learners. Denver: Love Publishing.

\section{Copyrights}

Copyright for this article is retained by the author(s), with first publication rights granted to the journal.

This is an open-access article distributed under the terms and conditions of the Creative Commons Attribution license (http://creativecommons.org/licenses/by/3.0/). 